\title{
EXHAUSTION AND REGENERATION IN 9/11 SPECULATIVE FICTION: KRIS SAKNUSSEMM'S “BEYOND THE FLAGS” $(2015)^{1}$
}

\author{
SONIA BAELO-ALLUÉ \\ Universidad de Zaragoza \\ baelo@unizar.es
}

Received 14 July 2018

Accepted 17 December 2018

KEYWORDS: 9/11 fiction; speculative fiction; blank fiction; trauma fiction; Kris Saknussemm; "Beyond the Flags;" Douglas Lain; In the Shadow of the Towers

PALABRAS CLAVE: Ficción del 11 de septiembre; ficción especulativa; blank fiction; ficción de trauma; Kris Saknussemm; "Beyond the Flags;" Douglas Lain; In the Shadow of the Towers

\begin{abstract}
Early 9/11 fiction has often been criticised for focusing too much on the victims and on the local aspects of the tragedy ignoring the global and political consequences of the attacks. 9/11 speculative fiction writers have taken longer to engage directly with the tragedy and when doing so they have also often adopted trauma-oriented approaches that could appease but not challenge. In 2015 Douglas Lain edited In the Shadow of the Towers: Speculative Fiction in a Post9/11 World, a collection that shows how the idiom of the fantastic can be serious and meaningful and also a means to explore cultural anxieties in the United States. Within Lain's collection, this paper pays special attention to Kris Saknussemm's "Beyond the Flags," a story that combines cultural anxieties of our time and helps readers confront their own contradictions by questioning accepted assumptions like the sacred nature of the victims or the expected
\end{abstract}

1 The research carried out for the writing of this article is part of a project financed by the Spanish Ministry of Economy and Competitiveness and the European Regional Development Fund (ERDF) (code FFI2015-63506). The author is also grateful for the support of the Aragonese Regional Government (DGA), the University of Zaragoza and the Fundación Ibercaja (JIUZ-2017-HUM-02). 
patriotism following a national tragedy. It also suggests new ways in which speculative fiction can offer original approaches to regenerate 9/11 fiction.

\section{RESUMEN}

Los primeros ejemplos de ficción del 11 de septiembre se han criticado a menudo por centrarse demasiado en las víctimas y en los aspectos locales de la tragedia ignorando las consecuencias políticas y globales de los ataques. Los escritores de ficción especulativa del 11 de septiembre han tardado más en tratar la tragedia directamente y cuando lo han hecho han adoptado a menudo aproximaciones orientadas al trauma con el objetivo de pacificar más que cuestionar. En 2015 Douglas Lain editó In the Shadow of the Towers: Speculative Fiction in a Post-9/11 World, una colección que demuestra que el idioma de lo fantástico puede ser serio y significativo además de un modo de explorar las ansiedades culturales en los Estados Unidos. Dentro de esta colección de Lain, este artículo presta especial atención a la historia corta de Kris Saknussemm "Beyond the Flags," una historia que combina las ansiedades culturales actuales y ayuda a los lectores a enfrentarse a sus propias contradicciones puesto que hace que el lector se cuestione suposiciones aceptadas como la naturaleza sagrada de las víctimas o el patriotismo esperable tras una tragedia nacional. La historia también sugiere nuevas maneras en que la ficción especulativa puede ofrecer formas originales de regenerar la ficción del 11 de septiembre.

\section{INTRODUCTION}

Since 9/11 fiction emerged seventeen years ago, it has evolved, been exhausted and regenerated. The initial hesitation that many writers felt when confronted with the possibility of dealing with the terrorist attacks gave way to hundreds of novels that have used 9/11 in some way in both literary and genre fiction ${ }^{2}$ and either as background

\footnotetext{
2 The terms literary fiction and genre fiction will be used throughout this essay for practical purposes. Traditionally, literary fiction has been understood as nonformulaic and character or theme driven, whereas genre fiction is often defined as formulaic and plot or narrative driven and includes different subcategories like romance, horror, fantasy, science fiction, mystery, among others. The boundaries between the two kinds of fiction can be blurry at times since there are many novels that incorporate elements of both but the distinction is still a useful one even if it has to be understood as guide rather than demarcated territory.
} 
setting, main topic or in indirect, allegorical ways. Well-known authors like Don DeLillo, Thomas Pynchon, Martin Amis, John Updike or Paul Auster have written 9/11 novels and the terrorist attacks have certainly marked the US literature of the first decade of the $21^{\text {st }}$ century. However, many of these initial novels have failed to meet the academics' high expectations of what a good 9/11 novel should be like as they are mainly trauma novels that do not deal with the global and political aspects of the tragedy. Within genre fiction 9/11 has also been a popular topic. However, speculative fiction, an umbrella term that includes fantasy, science fiction and horror, has taken longer to connect with the topic in meaningful ways. The criticism often levelled against this type of fiction is similar to the one expressed against 9/11 literary fiction, mainly that it focuses on the victims and on local aspects of the tragedy, offering conservative approaches in which there is no room for criticism of official ideologies. In fact, up to 2015 examples of 9/11 speculative fiction had been scattered and, academically, not very successful. In 2015 Douglas Lain edited In the Shadow of the Towers: Speculative Fiction in a Post- 9/11 World, the first collection of works of speculative fiction that, according to the book's blur, tries to answer the question: How can we continue to dream in the shadow of the towers? This collection is a turning point in the sense that it introduces new approaches to the tragedy that make use of the idiom of the fantastic in serious and meaningful ways as it offers ways to confront, rebuild and carry on. In this paper I will focus on one of the stories in the collection, Kris Saknussemm's "Beyond the Flags," because it is an excellent example of how to combine the tools that speculative fiction provides with the conventions of trauma fiction to question accepted assumptions about victims, heroes and tragedies. The story proves that the perspective that literary academics adopted rejecting local stories of trauma as a valid means to deal with $9 / 11$ in both literary and genre fiction may have been too Manichean as both the languages of the fantastic and of trauma can still cause wonder and bring about unconventional, original perspectives.

\section{9/11 TRAUMA FICTION AND 9/11 SPECULATIVE FICTION}

Both literary and genre fiction dealing with $9 / 11$ have been criticised by academics for similar reasons; mainly, the lack of a more critical stance and the use of too local approaches to the tragedy. In 2007 Pankaj Mishra was one of the first academics to complain that 9/11 
literary novels were mainly sentimental and nostalgic and limited their approach to the way New Yorkers coped with loss. Two years later, American Literary History published a seminal essay by Richard Gray and its response by Michael Rothberg who further developed Mishra's thesis. Gray denounced that the 9/11 novel had retreated into the world of domesticity, assimilating the unfamiliar into familiar structures, in narratives that followed the conventions of the trauma novel and ignored the panoramic and political aspects of the tragedy. Rothberg also saw this situation as a "failure of the imagination" as these novels could not capture the collective, cultural aspects of the tragedy and focused instead on single families, or specific victims. The tenth anniversary of the tragedy saw the publication of several academic essays and journal articles that reviewed the most important 9/11 novels and assessed their quality and main features (Crownshaw; Duvall and Marzec; Bond; Morley). The focus was on literary fiction, not genre fiction, and a certain consensus was reached in diagnosing that, by dealing with the victims of the tragedy and following the conventions of the trauma novel, the potential for social criticism or political comment was severely limited. The trauma novel internalises the gaps, uncertainties, dissociations and processes of traumatic experience into complex aesthetic structures (Vickroy, Reading Trauma Narratives 3), as it often departs from conventional linear sequence (Whitehead 6). Novels like Jonathan Safran Foer's Extremely Loud and Incredibly Close (2005), Jess Walter's The Zero (2006) and Don DeLillo's Falling Man (2007) could be examples of this category. What these critics and commentators were missing were novels that could deal with the political aspects of the tragedy and that would allow for social criticism beyond the political correctness that the trauma novel provides.

9/11 genre fiction has not been reviewed so thoroughly by academics. In fact, because of its popularity and accessibility genre fiction was initially rejected as a valid form to deal with the traumatic experience of 9/11. Some critics feared that popular culture could exploit the psychology of fear and simply offer tales of "terror, suspense, or prurience" (Vickroy, Trauma and Survival 2-3). As time has gone by, the acceptable forms to represent 9/11 have increased and genre fiction has also incorporated the tragedy in its formulaic patterns. For instance, we have 9/11 romance novels (Nicholas Sparks's Dear John [2006]), erotic thrillers (Lawrence Block's Small Town: A Novel Of New York [2003]), mystery novels (Jeffrey Archer's 
False Impression [2005]), alternate history (Matt Ruff's The Mirage [2012]) or time-travelling science fiction (Russell N. Reiling Jr.'s Ordinary Day [2014]). There have been several attempts to write 9/11 speculative fiction but so far, as Durrani claims, they have been scattered and not very successful. Science fiction has often dealt with other national traumas and upheavals like the threat of atomic warfare, the assassination of John F. Kennedy or the Vietnam War. However, as speculative fiction author Andrew Fox claims, 9/11 has been virtually absent from science fiction with the exception of a few short stories and novels, which in turn contrasts with the large number of mainstream novels that have dealt with the tragedy.

For speculative fiction writers $9 / 11$ was still more shocking and difficult to deal with because, as Douglas Lain claims in the introduction to his edited collection In the Shadow of the Towers, "our collective silver-screen fantasies had shattered the fourth wall, in a way that was chillingly similar to how we'd always depicted it happening, all the more horrible and terrible for being so recognizable" (2). Speculative fiction writers had to come to terms with the fact that the real world was science fiction, horror and fantasy and were challenged to write something new that still could generate wonder in the reader and compete with the real. Maybe due to this additional difficulty, writers have often dealt with 9/11 in more indirect ways. David M. Higgins in his study of US science fiction after 9/11 finds that the trope of the alien encounter became a major trend after $9 / 11$ in an atmosphere of perpetual crisis. The trope was used to interrogate "contemporary issues such as military interventions, surveillance, extraordinary rendition, and torture" (45). Aliens were portrayed as difficult to understand, inhuman, monstrous, and were not politically motivated, as they often functioned as allegories for terrorists. The continuous fear of invasion reflects the general atmosphere at the time as authorities and elites in these narratives are allowed to deploy emergency powers, mirroring the way George $\mathrm{W}$. Bush implemented measures like indefinite detention and the curtailing of civil rights. In these narratives the United States is often represented as the absolute victim and absolute moral authority, which leads Higgins to conclude that many of these narratives are reactionary since "Americans are invited to feel good about knowing what can be done in response to crises, and the question of what should be done is often rendered inconsequential" (49). 
This is an analysis that is shared with other critics like Lincoln Geraghty who in his review of American science fiction post$9 / 11$, especially focuses on the visual media and concludes that after an initial release of family films and comedies, some action blockbusters and films about 9/11 followed, but they mainly ignored national anxieties and showed the United States as triumphant and recovering. Science fiction films and mainstream television were omitting critique and context and TV series that seemed too similar to real events like The Lone Gunmen (2001) were cancelled for being too hard to watch. Film and TV looked at the past to find familiarity, reassurance and easily identifiable enemies and threats. Harris A. Durrani, who in his assessment of 9/11 speculative fiction in The New York Review of Science Fiction moves the focus to the written medium, also claims that post-9/11 speculative fiction has been a step backwards as he sees a paradigm shift from politics and culture to religion and extremism (8). He compares Frank Herbert's 1965 Dune and Mark Ruff's 2012 The Mirage. Whereas the former focuses on politics, the latter focuses on religion, losing the "political, cultural know-how of Dune" (9). He finds it difficult to find a positive post-9/11 speculative novel about the Muslim world that does not simplify to caricature. Fox, Higgins, Geraghty and Durrani agree that in most post-9/11 speculative fiction contemporary issues are only interrogated indirectly through allegorical readings of the alien encounter, the monstrous other or the zombie invasion. The US is always seen as the absolute moral authority, reinforcing the ideology of American exceptionalism. Even when speculative fiction deals directly with $9 / 11$, critique or proper explanation of context fails to appear as this fiction offers instead reassurance, resilience and recovery in narratives that often follow the conventions of trauma fiction.

In the four years that followed the attacks, four speculative fiction short stories were published dealing directly with 9/11 which could also be classified as examples of trauma fiction. They deal mainly with the experience of the victims and with the traumatic aspects of the tragedy and do not focus on the global, the political or the cultural context. As we have seen, this was the most popular approach to 9/11 in both literary and speculative fiction in the first years after the tragedy, an approach harshly criticised in the last few years by academics dealing with both types of fiction. Pat Forde's "In Spirit" (2002) deals with one of the 9/11 terrorists who, after being imprisoned for nearly 30 years, is offered the possibility of directly 
re-experiencing through a new technology called "deep-projection" the physical reality of the past without fully being part of it. He is sent back to the plane that crashed into the North Tower, to Ground Zero, to the inside of the South Tower... so that he can feel the fear, anguish and disbelief of the victims. Lucius Shepard's "Only Partly Here" (2003) deals with a volunteer clearing the debris at Ground Zero who after work always has a drink in a bar close by. A wallstreet-type woman also shows at the bar every evening and becomes friends with him without being aware that she is a deceased victim of the tragedy. Stephen King's "The Things They Left" (2005) deals with an employee on the $110^{\text {th }}$ floor at the World Trade Center that took the day off and survived the attacks. Items belonging to his deceased colleagues suddenly appear in his apartment and they reappear even after throwing them away. Only returning the items to the victims' family members makes his survivor's guilt fade away. Finally, Richard Bowes's "There's a Hole in the City," first published in 2005 and, like Kris Saknussemm's short story also included in Douglas Lain's In the Shadow of the Towers, deals with how victims of 9/11 start to walk the empty streets of New York together with other victims of former tragedies like the Triangle Shirtwaist Factory fire of 1911.

All these stories were published in the aftermath of the tragedy, which was a time of mourning and of coming to terms with the impact that 9/11 caused in a society that had never expected such an attack to the symbols of its world economic and political power: the Pentagon, the Twin Towers and probably the White House had the fourth plane, United Flight 93, not crashed in a field in Pennsylvania. These stories help readers work through the cultural trauma that 9/11 entailed as they imagine how terrorists could repent if they came to understand the suffering of the victims, how survivors have to accept the death of nearly 3000 people and their own survivors' guilt and how the tragedy connects to other historical moments of suffering for New York and the nation in general. In these approaches there is no room for the political; however, literature does not always have to be a political tool. As Catherine Morley puts it in her review of 9/11 literary fiction, literature cannot always deal with the narrowly political or the global. Other topics like the family and individual dramas of everyday life also need to play an important role (731).

The real problem with limiting speculative fiction to these trauma-oriented initial approaches is that the potential of the genre, 
which in part comes from its position outside the mainstream, is diminished. As Durrani underlines, speculative fiction has the power of capturing the concern of its society and "both the aspirations and anxieties of its audience as much as it reflects on the past, present, or future" (8). Good speculative fiction addresses and answers the social concerns by not merely inspiring but also challenging. The initial stories just mentioned reflect the social concern for the victims and the shock that the events produced, but they appease, they do not challenge. We also have to take into account that speculative fiction has tools that literary fiction lacks and that allow for the introduction of alternate history and alternative realities. As Oziewicz points out, speculative fiction can depart from consensus reality or embrace "a different version of reality than the empirical-materialist one" (2). This possibility helps speculative fiction to build a strong sense of awe and wonder. Mainstream authors have often used these tools and have blurred traditional genre boundaries (for example in slipstream fiction). ${ }^{3}$ Higgins mentions authors like Philip Roth, Paul Auster, George Saunders, Michael Chabon or Cormac McCarthy among others, and how science fiction has allowed them to explore and critique the US's response to crisis and disaster (51). In this sense, Andrew Fox believes that precisely because speculative fiction writers have special tools to inspire awe and wonder, tools that literary authors have often borrowed, it is even more difficult to understand why speculative writers have not had more to say regarding 9/11 and what it entails.

It is because of this dissatisfaction with the role that speculative fiction has played that the publication of Douglas Lain's edited collection In the Shadow of the Towers: Speculative Fiction in a Post-9/11 World in 2015 became a turning point. It includes excerpts from longer works and eighteen stories, some of which are reprints while others are originally written for the anthology. This collection has received mixed reviews since some literary critics have felt that allowing monsters, ghosts, aliens and the like into 9/11 narratives could trivialise the tragedy (Rothman). However, in the book's cover

\footnotetext{
3 The term "slipstream fiction" was coined by author Bruce Sterling, who in 1989 tried to find a word to refer to the kind of fiction that could not be understood as hard-core science fiction but could not be considered simply mainstream either. He felt that to a certain extent some mainstream authors were writing fiction that had fantastic elements in it like Toni Morrison's Beloved or Kurt Vonnegut's Galapagos, and were doing a better job of using such elements than conventional science fiction writers at the time.
} 
the idiom of the fantastic is defended as serious and meaningful and as providing ways to confront, rebuild and carry on. As Lain explains, when attempting to deal with 9/11 itself, many speculative writers chose to keep "dreams small, personal, and individual" (3) and he sees the stories in the collection in this light. He presents them as "small stories about a terribly huge event, but they manage to hold onto the fantastic, to hold onto wonder" (4). The first part "The dead" is about the victims, and they include zombies and ghosts who cannot find closure or go back home. These are stories about acting out and melancholia. The second part "Reaction and Repetition" is about coming to terms with the new situation and the fear of repetition and insecurity. The third part "The New Normal" is probably the most political as it questions the way people accepted the death of civil liberty and liberal democracy. The final part "Civilization?" looks beyond the here and now into the future and other civilizations to find new beginnings.

\section{KRIS SAKNUSSEMM'S "BEYOND THE FLAGS"}

Kris Saknussemm's "Beyond the Flags" is included in the first part of the collection dealing with "The dead." The story is very representative of what speculative fiction can offer when approaching 9/11. Paraphrasing Lain, it is a small story about a terribly huge event that can still cause wonder, shock and question established assumptions. It is a story worth exploring in full because in a way it represents the type of $9 / 11$ narrative that critics of both $9 / 11$ literary and speculative fiction have rejected as it seems a story that assimilates the unfamiliar into familiar structures. It focuses on the experience of one victim and approaches $9 / 11$ as an unexpected event that came out of nowhere and that does not seem to have any political or ideological roots or implications. It is a local story about a single New Yorker and does not consider the global or cultural consequences of the tragedy. In this sense, it is a story of trauma that focuses on the suffering of the victims and survivors, just like other speculative fiction stories mentioned before like Pat Forde's "In Spirit" (2002), Lucius Shepard's "Only Partly Here" (2003), Stephen King's "The Things They Left" (2005) or Richard Bowes's "There's a Hole in the City" (2005). What sets "Beyond the Flags" apart from other stories is that it breaks with well-established assumptions that emerged from 9/11 like the idea that all victims were exemplary and deserved unreserved social admiration or the idealization of victims, 
the police and fire officers. The story also works in opposition to George W. Bush's public speeches defending the United States as an exceptional nation attacked for its moral superiority ("President"). Even the Manichean dichotomy established by Bush between good and evil and victims and perpetrators ("Address") is challenged in the text. The victim is a perpetrator in his daily life that does not care for his child, is unfaithful and disrespectful to his wife and defrauds his clients and friends. Speculative fiction can reveal cultural anxieties and often has a cautionary function (Urbanski 2007). Kris Saknussemm's "Beyond the Flags" best shows these anxieties as he makes the reader question accepted assumptions about victims, heroes and tragedies.

It is the story of Paul Connors, a Wall Street narcissistic stockbroker who works in the South Tower at the World Trade Center. The morning of the attacks his wife phones him fearing he is dead only to discover he is with a lover and unaware of the attacks. What makes this short story an example of speculative fiction is the fact that, when Paul returns home to apologize, the person that opens the door explains that Mrs. Connors's husband died on 9/11. Apparently Paul has been "returning home" every 9/11 only to realise that he did die in the attacks. "Beyond the Flags" is similar to Ambrose Bierce's 1890 short story "An Occurrence at Owl Creek Bridge" that deals with a slave-owning Southern planter that is about to be hanged by the Union Army but apparently escapes only to find later that he has only been imagining his escape as his neck breaks and dies. What makes "Beyond the Flags" so compelling is the way the short story plays with our expectations since we do not know that Paul Connors has died on 9/11 until the end. In the story he is not presented in any positive light and does not seem to have any redeeming features. $\mathrm{He}$ is a shallow, status-obsessed, narcissistic executive that seems to fit the stereotype of the yuppie. The 9/11 plot twist makes readers reconsider Paul Connors and face their own forbidden thoughts about 9/11.

A visual example of the power of a tragedy of this type to change previous views and confront ideas that do not often come together can be seen in a very famous photo taken by Thomas Hoepker of Magnum Photos on the Brooklyn Esplanade on September 11, 2001 (Hoepker/Magnum). The photographer did not publish the image in the aftermath of $9 / 11$ because he felt it was ambiguous and confusing: 
Publishing it might distort the reality as we had felt it on that historic day. I had seen and read about the outpouring of compassion of New Yorkers toward the stricken families, the acts of

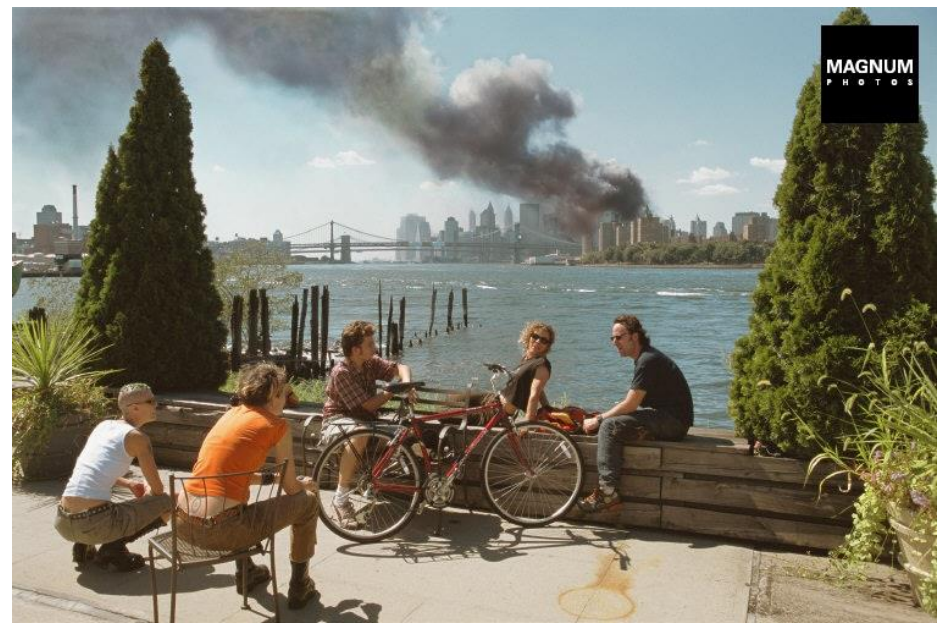

heroism by firefighters, police, and anonymous helpers. This shot didn't 'feel right' at this moment and I put it in the 'B' box of rejected images (Hoepker).

It seemed to tell the story of people who did not seem to care much about the attacks and this is a narrative hard to integrate in the official discourse of heroism and patriotism.

If we only focus on the lower half of the picture, we see a group of young people along the East River enjoying a sunny day out and chatting away, totally relaxed.

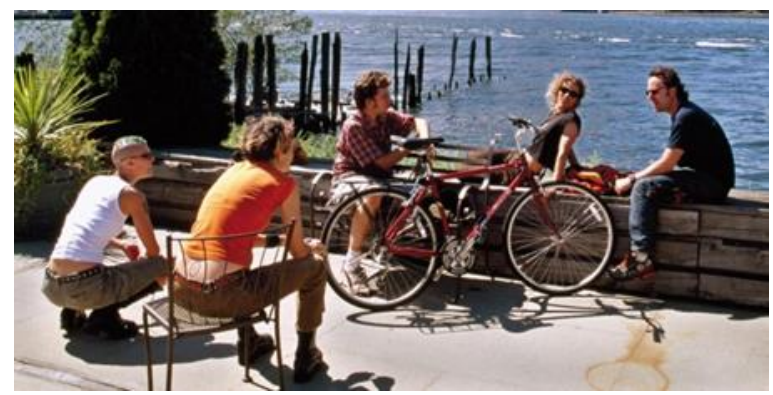


The full picture tells a different story as we see the huge plume of smoke rising from Lower Manhattan after the attack on the World Trade Center. Both narratives are easy to understand in individual terms; it is their juxtaposition that shocks the viewers and explains why it took four years to be finally published. It did not seem the appropriate response to the tragedy.

In "Beyond the Flags" we have a similar situation. The first half is a crude picture of a day in the life of a selfish and narcissistic executive obsessed with his possessions and unable to sympathise with others or think of their well-being. The second half is the story of the man becoming a victim of 9/11. In the aftermath of 9/11 all victims were depicted in heroic terms; they were publicly and privately mourned, and were presented in the best possible light, as could be seen in the posters for the missing and the obituaries published in The New York Times after 9/11. However, there were also "forbidden thoughts" that had to be repressed and that "Beyond the Flags" seems to reflect somehow. On September 7, 2002, Damien Cave wrote an article for Salon magazine called "Forbidden thoughts about 9/11" where a spectrum of improper responses to the terror attacks were presented. For example, a woman claimed:

I watched from my window, not on television, as the twin towers fell. As shocked as I was, I felt that this was not my problem as a black person. The people who worked at the World Trade Center were mostly white men, and so they had nothing to do with me as a black woman.

The idea that privileged people, white investment bankers were the main victims of the attacks, which, of course, is not necessarily the case, made this woman experience feelings of detachment from the victims. Another man explained that:

The deification of firefighters was the result of guilt. Most whitecollar people never think of blue-collar workers at all or dismiss them as insignificant. When yuppies realized that firefighters would brave flames to save their sorry, self-centered lives they suddenly became ridiculously reverential. There is no convert like a new convert.

For him the victims were also marked by social class, they were selfcentered white-collar affluent yuppies. Another man felt relief when he noted that banking is one of the few professions in NYC that gets 
going before 9 a.m: "Oh, it started before 9. The casualties will be investment bankers." These were anonymous voices but they were not the only ones. Ward Churchill, a professor at the University of Colorado at Boulder at the time of the attacks, described the workers in the Twin Towers as "Little Eichmanns" who deserved what happened to them for the way they profited from the suffering of others. He described those in the towers as:

[...] a technocratic corps at the very heart of America's global financial empire-the "mighty engine of profit" to which the military dimension of U.S. policy has always been enslavedand they did so both willingly and knowingly [...] More likely, it was because they were too busy braying, incessantly and selfimportantly, into their cell phones, arranging power lunches and stock transactions, each of which translated, conveniently out of sight, mind and smelling distance, into the starved and rotting flesh of infants. (2003)

Churchill lost his job in July 2007 after the controversy and a long legal process. His words are offensive and impossible to justify. However, the description of the victims he gives could also describe Paul Connors, the victim in "Beyond the Flags:" braying into a cell phone, arranging power lunches and stock transactions, obsessed with his own profit. The French philosopher Jean Baudrillard in his The Spirit of Terrorism (2002) also connected 9/11 to the tempting fantasy of destroying any power that has become hegemonic. While acknowledging that this is unacceptable to the Western moral conscience, he still claims that the emotive violence of all that has been said and written in the effort to dispel the fantasy leads to the conclusion that "they did it, but we wished for it" (5).

\section{1 "Beyond the Flags" as Blank Fiction}

Both the comments included in the 2002 Salon magazine article and even Ward Churchill and Jean Baudrillard's own have to do with well-established stereotypes that accompany yuppies, a term that started to be used in the 1980s and that refers to a generation of urban, affluent professionals-born between 1946 and 1964interested in their personal fulfilment, who desired the best of everything and were not afraid to make money fast. They were seen as narcissists and, by 2001, they were not especially popular for 
many Americans. In the American Psychiatric Association's Diagnostic and Statistical Manual of Mental Disorders (Fifth Edition), narcissistic personality disorder is defined as comprising "a pervasive pattern of grandiosity (in fantasy or behavior), need for admiration and a lack of empathy, beginning by early adulthood and present in a variety of contexts" (American Psychiatric Association, para. 301.81). In fiction there are many well-known examples of novels dealing with yuppies that reflect Wall Street's narcissistic and rapacious culture, like Tom Wolfe's The Bonfire of Vanities (1987), Bret Easton Ellis's American Psycho (1991) or Jay McInerney's Brightness Falls (1993). Most of "Beyond the Flags" follows the conventions of blank fiction, a literary movement that deals with crime, drugs, sexual excess, death, consumerism, media overload and subversion. Because of these subjects, the characters in these fictions are often unlikeable and hard to identify with. This literary approach lacks dense plots or elaborate styles as these authors favour instead "blank, atonal perspectives and fragile, glassy visions" (Annesley 2) and use a prose that can be defined as flat, affectless, uncommitted and distant. As a result, their characters are often unlikeable and excessive. Excess is a key term in these novels since they draw their material from the extreme particularities of the 1980 s and 1990s. However, what makes this writing especially controversial is the use of narrators that do not usually condemn the morally despicable acts described, which often makes the stories morally ambiguous.

In "Beyond the Flags" we find an omniscient third-person narrator that focalises on Paul Connors and who provides full access into his mind through free indirect discourse. This type of narrator allows for the presentation of facts external to the main character himself but it still reproduces the character's speech and thoughts, making the separation between the narrator and the character confusing at times. The morally ambiguous life of Paul is exposed through his own words and thoughts but we still have the external approach, which is especially useful when Paul's status as a dead victim of $9 / 11$ is revealed. The story opens with an ad for a very luxurious house that actually belongs to Paul. He carries a creased flyer in his briefcase with the real estate ad as a luck charm and as reminder of the success he has attained in finance, "the cutthroat, magical business" (32), as he defines it. Curiously enough, this is an ad for a real property that can be found in the Internet and that was originally listed for $\$ 6,475,000$ in June 2014 and was finally sold for 
\$3,250,000 in March 2015 ("97 Deep Valley Road, Stamford, CT 06903"). Paul's wealth and success is in part due to the power vacuum that his old friend and investment guide left when he killed himself after a business went wrong and after Paul set him up. His obsession with status is measured by the possessions he has. Not just the impressive house but also his car: "He didn't drive an Aston Martin Vanquish like Rudy Olson yet, but he had a daffodil-yellow Maserati Spyder" (32). The colour of the car could be a reference to Jay Gatsby's also yellow Rolls-Royce in The Great Gatsby since both characters share an obsession with luxury cars and flashy lifestyles.

In blank fiction there are references to specific products, real people and places that serve to portray a vivid depicture of late twentieth-century US life. As we have seen, the real estate ad that opens the story is a real ad for a very luxurious property in Deep Valley Road where Paul apparently lives. Besides, he also has a place for Sophie, his lover, in Upper Saddle River. He met her at the Zinc Bar in Manhattan. Context is also built through the incorporation of commercialised products creating a fiction that does not simply depict its own period but, as Annesley points out: "it speaks in the commodified language of its own period" (7). The characters in these fictions are clearly mass society members and as such they have no personality, instead, they speak through mass-culture references. People are not described in terms of personality and looks but by enumerating the brands they choose. Thus, Paul drives a daffodilyellow Maserati Spyder, buys a camisole and thong from Agent Provocateur for Sophie, drinks Piper-Heidsieck Champagne, wears a Rolex Submariner, has a Nokia mobile phone and a Montblanc fountain pen. Even Sophie is described as one of his possessions: "An iridescent little sapphire evening dress and chase-me-catch-me heels fresh out of a 34th Street box. She was always fresh out of the box. And what a box" (32). Joe Barnett, Paul's old friend and investment guide, ends up killing himself when a discrepancy in one of the holding accounts is found. He decided "to fall on his sword, in the form of a handful of Seconal and jelly jar of premium single malt in an Adirondack chair in the Hamptons" (32). Not any overdose but a Seconal overdose, not any whisky but sophisticated premium single malt, not any chair but an Adirondack chair, not anywhere but in the Hamptons.

Blank fiction also includes sexually explicit images and themes. This is the way Sophie is introduced: 
It wasn't just that Sophie was younger than his wife. [...] Her butthole was sweetly puckered but nearly unwrinkled [...] Her nipples were fiercely pronounced and sensitive. She could arch her back to make her body appear like some new kind of musical note. She fucked like a panther. [...] His wife barely ever groaned, even when he was pumped up. Sophie always knew what to say . . . from a wordless throaty murmur . . to "Oh daddy" . . . to "Fuck God, stick that big thing in my ass!" (32)

Paul's reaction when his wife tries to contact him on 9/11 fearing that he is trapped in one of the towers is very telling indeed:

What in hell did his wife want? After the Marshal Claver shakedown, he could get paranoid very quickly. He was particularly peeved because although he'd had an intense ejaculation the second round, he was still turgid. If Sophie polished the knob, he thought there might've been a possible shot at another erection--and that would've meant some anal penetration, which he prized more than an option bargain. The phone rang once more--and then once more. (34)

This passage is more shocking than the previous one because at this point the 9/11 narrative enters the story. This is when we start to get the full picture and, as we saw with Thomas Hoepker's photograph, 9/11 changes the narrative.

\section{2 "Beyond the Flags" as Trauma Fiction}

Paul has gone to Sophie's place rather than to the South Tower where he works and is oblivious to the tragedy. He describes the day as "clear crisp leaves-not-yet-turning Tuesday, September 11" (33). He just feels he has had a dream about a catastrophe and remembers a Montblanc pen slicing through the air into a wall but "[h]e'd never felt so alive" (34), as he claims. When talking to his wife, he is caught in the lie and watches on TV over and over again "the jets slash into the very building and the very section of the South Tower where he worked" (35). This obsession with the repetition of the images of the second plane hitting the tower is a phenomenon that according to Žižek forced viewers "to experience what the 'compulsion to repeat' and jouissance beyond the pleasure principle 
are: we wanted to see it again and again; the same shots were repeated ad nauseam, and the uncanny satisfaction we got from it was jouissance at its purest" (12). The jouissance produced by the TV images makes him take his car and go back to his wife to prevent the divorce that would ruin his lifestyle. In this way, the never ending repetition of the images works as foreshadowing of what will come next when Paul is caught in the compulsion to repeat his desperate journey back home to his wife every 9/11 anniversary only to be summoned back into the darkness beyond the flags.

It is at this point that the blank fiction narrative and the 9/11 trauma narrative merge and the discrepancy between the two becomes more obvious as we see the full picture:

Crisis management mode. His wife would be on the phone to a divorce lawyer at that very minute. Bells ringing, sirens wailing. There'd be knick-knacks thrown at him. Jagged tiles of ceiling insulation, exploding fluorescent lights. She'd have already frozen the joint accounts. Billowing ash and concrete rubble. The timeshare in the Bahamas would be out of the question. Collapsing girders, suffocating pleas. She'd find out about Sophie's place. Black clouds and flying bolts. The country club membership would be revoked. Mangled bodies, stampedes of burning secretaries. He might never step into the temperature-controlled mahogany crafted wine cellar again. Ralph and Jenny were probably blown to bits in the boardroom. (36)

Paul's shallowness, vanity, narcissism and obsession with social status is underlined by juxtaposing his trivial worries about the consequences of a divorce ("His wife would be on the phone...") with the consequences of the impact of the planes against the World Trade Center ("Bells ringing, sirens wailing...").

His wife would be on the phone to a divorce lawyer at that very minute $[\ldots]$

She'd have already frozen the joint accounts [...]

The timeshare in the Bahamas would be out of the question [...]

She'd find out about Sophie's place [...]

The country club membership would be revoked [...]

He might never step into the temperature-controlled mahogany crafted wine cellar again $[\ldots]$

Bells ringing, sirens wailing [...]

Jagged tiles of ceiling insulation, exploding fluorescent lights [...]

Billowing ash and concrete rubble [...] 
Collapsing girders, suffocating pleas [...]

Black clouds and flying bolts [...]

Mangled bodies, stampedes of burning secretaries [...]

Ralph and Jenny were probably blown to bits in the boardroom. (36)

The narrative of his shallow life starts to disintegrate as he reaches his street and notices the US flags planted all along the sides of the road that were not there before. Suddenly his neighbours have all become true patriots. In his house he finds Ms. Beatty, the woman that lives there now. Fragmented memories of 9/11 interrupt the linear conversation they have:

"As I told you last year, Mrs. Connors's husband died in the attack on the World Trade Center. She sold the house and moved to California. I believe she lives in the Los Angeles area now. I'm . . . very sorry." A murky brown moment overcame him, a slippage of track somewhere inside. Then a puzzle of plate glass consumed in a roaring mess of light. "I . . . should . . . go . . ." he managed to wheeze, his ears ringing. (39)

This fragmentation is characteristic of trauma novels as a form to represent the acting out of a traumatic experience. The symbolic replacement of a traumatic memory with a different image is also common as a way to deal with repressed experiences that cannot be brought to conscious memory. In the short story there is also the intrusive image of the Montblanc pen sailing through the air that stands for the plane hitting Paul's tower. This is typical of 9/11 trauma fiction and we find a similar example in DeLillo's Falling Man when Keith Neudecker keeps remembering a white shirt floating in the air that stands for a falling person he saw. In this sense, Paul also has a "peculiar falling feeling" (40) that suggests how he may have died.

The discovery that Paul is a ghost that tries to return home every $9 / 11$ is a plot twist also in terms of genre-from blank fiction to trauma fiction and to speculative fiction-and of perspective-from Paul as an unfaithful, narcissistic, money-obsessed victimiser into a random, undeserving victim of 9/11. The account of his 9/11 morning with Sophie had been a lie since at the last minute that morning he had changed his mind and "he'd done the right thing" (40). Paul is trapped in melancholic repetition. Much has been written between the difference between mourning and melancholia, but going back to Sigmund Freud, both mourning and melancholia 
are reactions to a loss; in Paul's case, he has lost his own life, and they imply "a profoundly painful dejection, cessation of interest in the outside world, loss of the capacity to love, inhibition of all activity" (244). However, melancholia also implies "a lowering of the self-regarding feelings to a degree that finds utterance in selfreproaches and self-revilings, and culminates in a delusional expectation of punishment" (244). Paul's self-reproach is seen at the end when he judges himself in very negative terms. In the final moment of realization, he confesses that not just that morning but his entire life had been a lie: "From cheating at Yale, to defrauding his clients, and setting up his mentor and loyal business partner-to sneaking around on his wife, ignoring his son" (40). This self-loathing leads to the final acceptance of his own death which is still presented by juxtaposing the shallow and the deep: "The hideous trauma would pass, like another neighbor's luxury sedan" (40).

\section{CONCLUSION}

The story combines cultural anxieties of our time, like the dislike for Wall Street "Masters of the Universe," together with the fear of terrorism and the sympathy that victims attract. These cultural anxieties are represented in this genre-bending short story by combining blank fiction, trauma fiction and speculative fiction. Cultural anxieties and forbidden thoughts are allowed to cross because the story provides the narrative means to combine both types of anxieties. Žižek has claimed that late-capitalist consumerist society creates a fake world, a fiction that keeps people happy and productive preventing them from seeing how their lives are "unreal, substanceless, deprived of material inertia" (13). The immersion in consumer culture, as exemplified in Paul's life in the story, creates a despiritualized universe that dematerializes "real life" which reverses "into a spectral show" (Žižek 14). 9/11 brought the real and shattered the illusion of an idyllic life. This is what happens to Paul as he realises that his being dead is more real than his former fake life.

The story proves that $9 / 11$ fiction can still be politically relevant and ideologically challenging when dealing with small stories of individual victims presented in trauma structures. Much speculative fiction has followed this path and even though the fear that limiting 9/11 fiction to trauma fiction may depoliticise the tragedy, it can also be used to play with our expectations and with 
the most established social assumptions like the sacred nature of the victims or the compulsory patriotism following a national tragedy. Speculative fiction is at its best when the power to wonder becomes the power to explore the taboos and question the official policies of the time. It is at its best when it goes beyond the flags, beyond the obvious patriotism and explores the darkness of what we cannot face.

\section{WORKS CITED}

“97 Deep Valley Road, Stamford, CT 06903.” ColdwellBankerHomes.com, www.coldwellbankerhomes.com/ct/stamford/97-deep-valleyroad/pid_936149/

AMERICAN PSYCHIATRIC ASSOCIATION. (2013). "Personality Disorders." Diagnostic and Statistical Manual of Mental Disorders (5th ed.), 2013, doi:10.1176/appi.books.9780890425596.dsm18.

ANNESLEY, James. Blank Fictions: Consumerism, Culture and the Contemporary American Novel. Pluto, 1998.

BOND, Lucy. "Compromised Critique: A Meta-critical Analysis of American Studies after 9/11." Journal of American Studies, vol. 45, no. 4, 2011, pp. 733-56.

BAUDRILLARD, Jean. The Spirit of Terrorism and Other Essays, translated by Chris Turner. Verso, 2002.

BIERCE, Ambrose. "An Occurrence at Owl Creek Bridge." 1890. The Complete Short Stories of Ambrose Bierce, edited by Ernest Jerome, Doubleday, 1970, pp. 305-13.

BOWES, Richard. "There's a Hole in the City." 2005. In the Shadow of the Towers: Speculative Fiction in a Post-9/11 World, edited by Douglas Lain, Night Shade Books, 2015, pp. 9-25.

BUSH, George. "Address to a Joint Session of Congress and the American People." The White House: President George W. Bush. Archives, 20 Sept. 2001, georgewbushwhitehouse.archives.gov/news/releases/2001/09/20010920-8.html

BUSH, George. "President Delivers 'State of the Union." The White House: President George W. Bush. Archives, 29 Jan. 2002, georgewbush- 
whitehouse.archives.gov/news/releases/2002/01/2002012911.html

CAVE, Damien. "Forbidden Thoughts About 9/11: The Readers Respond." Salon, 7 Sept. 2002, www.salon.com/2002/09/07/forbidden_2.

CHURCHILL, Ward. “'Some People Push Back:' On the Justice of Roosting Chicken." Kersplebedeb, 2003, kersplebedeb.com/mystuff/s11/churchill.html

CROWNSHAW, Richard. "Deterritorializing the 'Homeland' in American Studies and American Fiction after 9/11." Journal of American Studies, vol. 45, no. 4, 2011, pp. 757-76.

DURRANI, Haris. "The Failure of Post-9/11 Science Fiction." New York Review of Science Fiction, vol. 25, no.1, 2012, pp. 8-12.

DUVALL, John N. and Robert P. Marzec. "Narrating 9/11." MFS Modern Fiction Studies, vol. 57, no. 3, 2011, pp. 381-400.

FORDE, Pat. "In Spirit." Analog: Science Fiction and Fact, vol. 122, no.9, Sept. 2002, pp. 10-51.

FOX, Andrew. "The Absence of 9-11 from Science Fiction." Fantastical Andrew Fox, 11 Sept. www.fantasticalandrewfox.com/articles/absence-of9-11-fromscience fiction

FREUD, Sigmund. "Mourning and Melancholia." 1917. The Standard Edition of the Complete Psychological Works of Sigmund Freud, vol. 14, The Hogarth Press, 1986, pp. 239-260.

GERAGHTY, Lincoln. "American Science Fiction Post-9/11." American Science Fiction Film and Television. Bloomsbury, 2009, pp. 103-121.

GRAY, Richard. "Open Doors, Closed Minds: American Prose Writing at a Time of Crisis." American Literary History, vol. 21, no. 1, 2009, pp. 128-51.

HIGGINS, David M. "American Science Fiction after 9/11." The Cambridge Companion to American Science Fiction, edited by Eric Carl Link and Gerry Canavan, Cambridge University Press, 2015. 
HOEPKER/MAGNUM PHOTOS. Image Reference NYC14238 (HOT2001009K004). Magnum Photos, pro.magnumphotos.com/Asset/-2K7O3RK0762.html

HOEPKER, Thomas. "I Took That 9/11 Photo." Slate, 14 Sept. 2006, www.slate.com/id/2149675.

KING, Stephen “The Things They Left." Transgression, edited by Ed McBain, Forge, 2005, pp. 1-58.

LAIN, Douglas, editor. In the Shadow of the Towers: Speculative Fiction in a Post-9/11 World. Night Shade Books, 2015.

MISHRA, Pankaj. "The End of Innocence." The Guardian, 19 May, 2007, www.theguardian.com/books/2007/may/19/fiction.martinamis/.

MORLEY, Catherine. “'How Do We Write about This?' The Domestic and the Global in the Post-9/11 Novel." Journal of American Studies, vol. 45, no. 4, 2011, pp. 717-31.

OZIEWICZ, Marek. "Speculative Fiction." Oxford Research Encyclopedia of Literature. 2017, pp. 1-27, doi:10.1093/acrefore/9780190201098.013.78.

ROTHBERG, Michael. "A Failure of the Imagination: Diagnosing the Post9/11 Novel: A Response to Richard Gray." American Literary History, vol. 21 , no. 1, 2009, pp. 152-8.

ROTHMAN, Joshua. "The Unsettling Arrival of Speculative 9/11 Fiction." The New Yorker, 11 Sept. 2015, www.newyorker.com/culture/culturalcomment/the-creepy-power-of-speculative-911-fiction/.

SAKNUSSEMM, Kris. "Beyond the Flags." In the Shadow of the Towers: Speculative Fiction in a Post-9/11 World, edited by Douglas Lain, Night Shade Books, 2015, pp. 31-41.

SHEPARD, Lucius. "Only Partly Here.” Asimov's Science Fiction, March 2003, pp. 38-56.

STERLING, Bruce. "Slipstream". SF Eye, no. 5, July 1989, www.journalscape.com/jlundberg/page2

THOMAS, Paul L. Science Fiction and Speculative Fiction: Challenging Genres. Sense Publishers, 2013. 
URBANSKI, Heather. Plagues, Apocalypses and Bug-Eyed Monsters: How Speculative Fiction Shows Us Our Nightmares. McFarland, 2007.

VICKROY, Laurie. Trauma and Survival in Contemporary Fiction. University of Virginia Press, 2002.

VICKROY, Laurie. Reading Trauma Narratives: The Contemporary Novel and the Psychology of Oppression. University of Virginia Press. 2015.

WHITEHEAD, Anne. Trauma Fiction. Edinburgh UP, 2004.

ŽIŽEK, Slavoj. Welcome to the Desert of the Real! Five Essays on September 11 and Related Dates. Verso, 2002. 